\title{
Stem Cells and Development
}

Stem Cells and Development: http://mc.manuscriptcentral.com/scd

\section{Licensing by inflammatory cytokines abolishes heterogeneity of immunosuppressive function of mesenchymal stem cell population}

\begin{tabular}{|c|c|}
\hline Journal: & Stem Cells and Development \\
\hline Manuscript ID: & SCD-2014-0581.R2 \\
\hline Manuscript Type: & Original Research Report \\
\hline Date Submitted by the Author: & $n / a$ \\
\hline Complete List of Authors: & $\begin{array}{l}\text { Szabó, Enikő; Biological Research Centre, Hungarian Academy of Sciences, } \\
\text { Institute of Genetics } \\
\text { Fajka-Boja, Roberta; Biological Research Centre, Hungarian Academy of } \\
\text { Sciences, Institute of Genetics } \\
\text { Kriston-Pál, Éva; Biological Research Centre, Hungarian Academy of } \\
\text { Sciences, Institute of Genetics } \\
\text { Hornung, Ákos; Biological Research Centre, Hungarian Academy of } \\
\text { Sciences, Institute of Genetics } \\
\text { Makra, Ildikó; Biological Research Centre, Hungarian Academy of Sciences, } \\
\text { Institute of Genetics } \\
\text { Kudlik, Gyöngyi; National Blood Service, Stem Cell Biology Unit } \\
\text { Uher, Ferenc; National Blood Service, Stem Cell Biology Unit } \\
\text { Katona, Róbert; Biological Research Centre, Hungarian Academy of } \\
\text { Sciences, Institute of Genetics } \\
\text { Monostori, Éva; Biological Research Centre, Hungarian Academy of } \\
\text { Sciences, Institute of Genetics } \\
\text { Czibula, Ágnes; Biological Research Center, Institute of Genetics }\end{array}$ \\
\hline Keyword: & MSC \\
\hline Abstract: & $\begin{array}{l}\text { When mesenchymal stem cells (MSC) are used for therapy of } \\
\text { immunological pathologies, MSCs get into an inflammatory environment } \\
\text { altering the effectiveness of the treatment. To establish the impact of } \\
\text { environmental inflammatory factors on MSC's immunofunction in the mirror } \\
\text { of intrinsic heterogeneity of mouse MSC population, individual MSC clones } \\
\text { were generated and characterized. Adipogenic but not osteogenic } \\
\text { differentiation and pro-angiogenic activity of five independent MSC cell } \\
\text { lines were similar. Regarding osteogenic differentiation, clones MSC3 and } \\
\text { MSC6 exhibited poorer capacity than MSC2, MSC4 and MSC5. To study the } \\
\text { immunosuppressive heterogeneity, in vitro and in vivo experiments have } \\
\text { been carried out using T-cell proliferation assay and delayed-type } \\
\text { hypersensitivity (DTH) response, respectively. Remarkable difference was } \\
\text { found between the clones in their ability to inhibit T-cell proliferation in the } \\
\text { following order: MSC2 } \geq \text { MSC5>MSC4>MSC3>>MSC6. Nevertheless, the } \\
\text { differences between the immunosuppresive activities of the individual } \\
\text { clones disappeared upon pre-treatment of the cells with pro-inflammatory } \\
\text { cytokines, a procedure called licensing. Stimulation of all clones with IFN-Y }\end{array}$ \\
\hline
\end{tabular}


and TNF-a resulted in elevation of their inhibitory capability to similar level. Nitric oxide (NO) and prostaglandin E2 (PGE2) were identified as major mediators of immunofunction of the MSC clones. The above findings were also supported by in vivo results. Without licensing, MSC2 inhibited, while MSC6 did not affect DTH response. In contrast, pre-stimulation of MSC6 with inflammatory cytokines resulted in strong suppression by this clone as well. Here we have showed that MSC population is functionally heterogeneous in term of immunosuppressive function, however, this variability is largely reduced under pro-inflammatory conditions.

\section{SCHOLARONE ${ }^{\text {m }}$}

Manuscripts 
Licensing by inflammatory cytokines abolishes heterogeneity of immunosuppressive function of mesenchymal stem cell population

Enikő Szabó", Roberta Fajka-Boja*, Éva Kriston-Pál, Ákos Hornung, Ildikó Makra, Gyöngyi

Kudlik $^{1}$, Ferenc Uher ${ }^{1}$, Róbert László Katona, Éva Monostori, Ágnes Czibula ${ }^{\#}$

Institute of Genetics, Biological Research Centre, Hungarian Academy of Sciences, Szeged, Hungary

${ }^{1}$ Stem Cell Biology Unit, National Blood Service, Budapest, Hungary

Running title: Heterogeneity of immunological function of MSCs

*Authors contributed equally to the paper

\# Corresponding author:

Ágnes Czibula

Institute of Genetics, Biological Research Centre, Hungarian Academy of Sciences

62 Temesvári krt, Szeged, 6726 Hungary

Tel: 36-62-599-684, Fax: 36-62-433-503

E-mail: czibula.agnes@brc.mta.hu 


\begin{abstract}
Authors' informations:
\end{abstract}
Enikő Szabó, Roberta Fajka-Boja, Éva Kriston-Pál, Ákos Hornung, Ildikó Makra, Róbert László

Katona, Éva Monostori:

Institute of Genetics, Biological Research Centre, Hungarian Academy of Sciences

62 Temesvári krt, Szeged, 6726 Hungary

Tel: 36-62-599-684, Fax: 30-62-433-503

E-mail adresses:

ES: szabo.eniko@brc.mta.hu

RFB: fajka_boja.roberta@brc.mta.hu

EKP: kriston_pal.eva@brc.mta.hu

AH: hornung.akos@brc.mta.hu

IM: mildicko@gmail.com

RLK: katona.robert@brc.mta.hu

EM: monostori.eva@brc.mta.hu

Gyöngyi Kudlik and Ferenc Uher

Stem Cell Biology Unit, National Blood Service

64 Diószegi út, Budapest, 1113 Hungary

Tel: 36-1- 372-4151, Fax: 36-1-372 4352

E-mail addresses:

GK: gyongyi0888@gmail.com

FU: uher.ferenc@gmail.com 


\section{Introduction}

Mesenchymal stem or stromal cells are adult multipotent fibroblast-like progenitor cells present in the bone marrow and virtually in all other organs [1]. The major criteria to define MSCs are the plastic adherence in standard culturing conditions, in vitro differentiation capacity toward mesodermal lineages i.e., osteoblasts, chondroblasts and adipocytes and the expression of specific set of immunophenotypic markers [2]. Moreover, a powerful immunosuppressive activity also characterizes MSCs, particularly those isolated from the bone marrow or adipose tissue [3]. Due to the ability of differentiation into various tissues and immunomodulatory function MSCs have been suggested as a potential tool in regenerative and immunosuppressive medicine. Therefore, the safety and efficacy of using MSCs for the treatment of various pathological conditions have recently been a matter of intensive investigation $[4,5]$. Therapy of severe refractory acute graft-versus-host disease (GVHD) [6] has already received conditional approval in several countries. Moreover, treatment of myocardial infarction is one of the most successful clinical improvements being at phase II clinical trial [7,8]. Benefits of MSC therapy originate from that the MSCs promote tissue regeneration via differentiation and engraftment into the injured recipient tissue and/or production of wide panel of bioactive molecules supporting angiogenesis, stimulating endogenous stem cell recruitment and differentiation, modulating immune response by diminishing inflammation [9]. Although growing body of data has been accumulated suggesting clonal heterogeneity of MSCs, it is still not well established, how the heterogeneity of MSC population affects the therapeutical application.

The heterogeneity of MSCs has been demonstrated regarding morphology, cell surface marker expression, differentiation potential and transcriptome [10-12]. It was first proposed by Friedenstein and his colleagues who described variable osteogenic potential of bone marrow- 
derived fibroblastoid colonies in vivo [13]. This study was followed by more than a dozen studies showing that MSC clones displayed various capacity of multilineage differentiation in vitro and in vivo (reviewed in [10]). On the other hand, immunosuppressive functions of single cell-derived MSC populations have been improperly compared. The few studies available resulted in controversial data showing either similar or different immunomodulatory capacities of single cell-derived MSC lines [14-16]. Recent findings have provided evidence that the immunosuppressive function of these cells is modulated by an inflammatory microenvironment $[15,17]$. Whether licensing by pro-inflammatory cytokines affects the immunosuppressive function at clonal level has not yet been revealed.

The current work aims to explore the heterogeneity of mouse bone marrow derived MSC population with a special focus on the consequence of the heterogeneity to the immune function. Differentiation properties and pro-angiogenic activities are characterized at clonal level. Our results show that the analyzed 5 MSC clones are similar in immunophenotype, adipogenic differentiation and pro-angiogenic activity. Two clones, MSC3 and MSC6 show poorer capacity to differentiate toward osteogenic direction. Most importantly, remarkable differences are observed in immunosuppressive capabilities between the individual clones both in vitro and in vivo. However, the variability in the immune function disappears when MSCs are licensed by inflammatory cytokines indicating that the functions of individual cells are largely dependent on their surrounding environment. 


\section{Materials and Methods}

\section{Cell culture}

Mesenchymal stem cells were isolated from bone marrow of one C57BL/6 mouse and characterized as described previously $[18,19]$. The cells were cultured in DMEM (Gibco ${ }^{\circledR}$ ) supplemented with $10 \%$ fetal bovine serum (FBS) $\left(\mathrm{Gibco}^{\circledR}\right)$, penicillin-streptomycin (SigmaAldrich) and $2 \mathrm{mM} \mathrm{L}$-glutamine $\left(\right.$ Gibco $\left.^{\circledR}\right)$ (complete medium, CM) in a humidified incubator with $5 \% \mathrm{CO}_{2}$ at $37^{\circ} \mathrm{C}$.

MSC culture at passage 10 was cloned with limiting dilution in DMEM/F-12 $\left(\right.$ Gibco $\left.^{\circledR}\right)$ supplemented with $10 \%$ FBS and $5 \%$ horse serum $\left(\right.$ Gibco $\left.^{\circledR}\right)$ by plating 1 cell/well in a 96 -well culture plate (Orange Scientific). Five monoclonal MSC cultures labeled as MSC2-6 were randomly selected under a CKX41 inverted light microscope (Olympus Holding Europa GmbH) and further cultured up to 5-10 passages.

\section{Flow cytometry}

Cells $\left(5 \times 10^{5}\right.$ cells/sample $)$ were labeled for 30 min at $4{ }^{\circ} \mathrm{C}$ with various antibodies: antimouse Sca-1 labeled with phycoerythrin (PE), CD44-PE, biotin-conjugated CD119 (BD Pharmingen) followed by streptavidin-PE (Sigma-Aldrich). Mouse Mesenchymal Stem Cell Marker Antibody Panel (BD Pharmingen) was used to analyze CD11b, CD45, CD29 and CD106 according to manufacturer's instructions. The proper isotype matched immunoglobulins were used as controls. Cell analysis was performed by FACSCalibur flow cytometer (Becton Dickinson). Evaluation of the data was carried out with CellQuest ${ }^{\mathrm{TM}}$ software (Becton Dickinson). 


\section{Detection of adipogenic and osteogenic differentiation}

Adipogenic medium consisted of DMEM/F-12 supplemented with 10\% FBS, penicillinstreptomycin, $\quad 0.5 \mathrm{mM} \quad$ 3-isobutyl-1-methylxanthine $\quad$ (IBMX; Sigma-Aldrich), $\quad 10 \mu \mathrm{M}$ dexamethasone (Sigma-Aldrich), $66 \mu \mathrm{M}$ indomethacin (Sigma-Aldrich), $2 \mu \mathrm{L} / \mathrm{mL}$ insulin (insulin lispro injection, $100 \mathrm{U} / \mathrm{mL}$, Humalog $^{\mathbb{B}}$ ) [20]. MSCs were maintained in adipogenic medium for 3 days, detached with $0.05 \%$ trypsin-EDTA, fixed with $4 \%$ paraformaldehyde (Sigma-Aldrich) and lipid droplets were stained with fluorescent AdipoRed ${ }^{\mathrm{TM}}$ according to the manufacturer's instructions (Lonza). Fluorescent lipid droplets were detected with Axioskop 2 Mot fluorescence microscope (Carl Zeiss) using EC Plan-Neofluar 20x/0.5 objective (Carl Zeiss). For quantitation of lipid accumulation in adipocytes, the cells $\left(5 \times 10^{5}\right.$ cells/sample) were labeled with AdipoRed $^{\mathrm{TM}}$ as described above and quantified by FACSCalibur flow cytometer using CellQuest $^{\mathrm{TM}}$ software.

Osteogenic medium was composed of $\mathrm{CM}$ and $10 \mathrm{mM} \beta$-glycerophosphate (SigmaAldrich), $50 \mu \mathrm{g} / \mathrm{mL}$ L-ascorbic acid 2-phosphate (Sigma-Aldrich) and $0.1 \mu \mathrm{M}$ hydrocortisone (Sigma-Aldrich). MSCs were cultured in osteogenic medium for 14 days then fixed with $8 \%$ formaldehyde and stained with Alizarin Red S (Sigma-Aldrich) solution ( $\mathrm{pH} 4.1)$ to detect calcium deposition. Photomicrographs were taken with Olympus CKX41 inverted light microscope and Olympus Camedia C-5060 camera (Olympus Holding Europa GmbH).

In vitro pre-vascular structure assay

Co-culture of MSCs and mouse heart endothelioma cells, H5V (kindly provided by Vizler C of HAS, BRC, Hungary) [21] was initiated in a ratio of $1: 1$ in a 24-well plate at a cell density of $2 \times 10^{4}$ cells/well. Pre-vascular structure formation was evaluated as follows: 5 randomly 


\section{T-cell proliferation assay}

First, MSCs were seeded on a 96-well plate at cell density of $5 \times 10^{3}$ cells $/ 100 \mu \mathrm{L}$ CM in a well. Mesenteric, inguinal and brachial lymph nodes from Balb/C mice were dissected. Lymph nodes were disrupted mechanically to release most of the leukocytes. Leukocytes were harvested by centrifugation and resuspended in phosphate buffered saline (PBS) containing 5\% FBS at a final concentration of $2 \times 10^{6}$ cells $/ \mathrm{mL}$. Carboxyfluorescein diacetate succinimidyl ester (CFSE, CellTrace ${ }^{\mathrm{TM}}$ CFSE Cell Proliferation Kit, Life Technologies) was added to leukocytes at a final concentration of $2.5 \mu \mathrm{M}$ and cells were incubated in dark for 5 minutes at room temperature. Leukocytes were washed twice with fresh RPMI culture medium $\left(\right.$ Gibco $\left.^{\circledR}\right)$ then $2 \times 10^{5}$ cells were added to the pre-seeded MSCs in $100 \mu \mathrm{L}$ of RPMI containing $10 \% \mathrm{FBS}, 50 \mu \mathrm{M} \beta$ mercaptoethanol (Sigma-Aldrich) and $5 \mu \mathrm{g} / \mathrm{mL}$ Concanavalin A (ConA, Sigma-Aldrich). In blocking experiments, nitric oxide synthase (NOS2), prostaglandin-endoperoxide synthase 2 (cyclooxygenase 2) (PTGS2) or indolamine-2,3-dioxygenase (IDO) inhibitors, 1 mM N ${ }^{\mathrm{G}}$-methylL-arginine acetate salt, L-NMMA (Sigma-Aldrich), $10 \mu \mathrm{M}$, indomethacin (Sigma-Aldrich) or $1 \mathrm{mM}$ 1-methyl-L-tryptophan (Sigma-Aldrich), respectively were added to MSC/leukocyte cocultures. After $72 \mathrm{~h}$ of incubation, non-adherent leukocytes were collected, washed with PBS, settled by centrifugation and resuspended in PBS supplemented with $1 \%$ FBS, $0.1 \%$ sodiumazide (FACS-buffer) and $10 \mu \mathrm{g} / \mathrm{mL}$ propidium-iodide. Cell proliferation was measured by flow 
Western blot analysis

Mesenchymal stromal cells were lysed $\left(10^{7} \mathrm{MSCs} / \mathrm{mL}\right)$ in RIPA buffer containing $10 \mathrm{mM}$ Tris $\bullet \mathrm{HCl}$ and $150 \mathrm{mM} \mathrm{NaCl}$ (Molar Chemicals), 1\% Triton X (Sigma-Aldrich), 0.5\% sodium deoxycholate (Reanal), 0.1\% SDS (Sigma-Aldrich), $2 \mathrm{mM}$ EDTA (Reanal) and $1 \mathrm{mM}$ PMSF (Sigma-Aldrich). The lysates were analyzed by Western blotting after running the samples on a $10 \%$ SDS-polyacrylamide gel then electroblotted onto a nitrocellulose membrane (Whatman ${ }^{\circledR}$ Protran ${ }^{\circledR}$ ). After blocking with 3\% cold fish gelatin (Sigma-Aldrich) in Tris buffered saline (TBS) and $0.05 \%$ Tween $^{\circledR} 20$ (Sigma-Aldrich), the membranes were incubated with rabbit anti-Gal-1 (produced in our laboratory, [19]) then HRP-conjugated anti-rabbit immunoglobulin (Dako). Rabbit anti- $\beta$-actin antibody (Abcam) was used as a loading control. Immunoreactive proteins were visualized with Amersham ${ }^{\mathrm{TM}}$ ECL Prime Western Blotting Detection Reagent (GE Healthcare Life Sciences) and analyzed using EC3 Imaging System furnished with a CCD Chemi 410 Camera (Ultra-Violet Products). As molecular mass standard, Page Ruler ${ }^{\mathrm{TM}}$ Prestained 


\section{Quantitative real-time PCR}

MSCs $\left(10^{5}\right.$ cells/well) were plated in $35 \mathrm{~mm}$ diameter culture dishes in CM. After $24 \mathrm{~h}$, fresh $\mathrm{CM}$ was added with or without $100 \mathrm{ng} / \mathrm{mL}$ IFN- $\gamma$ and $50 \mathrm{ng} / \mathrm{mL}$ TNF- $\alpha$ then further incubated for $24 \mathrm{~h}$. Finally, total RNA was extracted using Nucleospin RNA II isolation kit (MACHEREY-NAGEL GmbH) according to manufacturer's instruction. RevertAid H Minus First Strand cDNA Synthesis Kit (Thermo Fisher Scientific Inc.) was used to obtain cDNA from $2 \mu \mathrm{g}$ of total RNA/reaction. Quantitative PCR (qPCR) was performed using TaqMan ${ }^{\circledR}$ Gene Expression Master Mix (Life Technologies) for Ptgs2, Nos2 and Ido1 and AccuPower ${ }^{\circledR} 2 \mathrm{X}$ Greenstar qPCR Master Mix (Bioneer) for angiopoietin-1 (Angpt1), vascular endothelial growth factor A (Vegfa), transforming growth factor beta 1 (Tgfb1) and galectin-1 (Lgals1) in RotoGene3000 instrument (Corbett Life Science). Relative gene expression normalized to glyceraldehyde 3-phosphate dehydrogenase (Gapdh) was presented as $2^{\text {(CtGapdh-CtGOI) }}$. TaqMan ${ }^{\circledR}$ Gene Expression Assays were commercially available for Ptgs2 (Mm00478374_m1), Nos2 (Mm01309902_m1), Ido1 (Mm00492586_m1*) and Gapdh (Mm99999915_g1). Primers for qPCR were designed using Universal Probe Library Assay Design program (Roche Applied Science) for Gapdh, Angpt1, Lgals1, Tgfbl and Vegfa. The following primer sequences were used: Gapdh fwd: tttgatgttagtggggtctcg, rev: agcttgtcatcaacgggaag; Angpt1 fwd: cggatttctcttcccagaaac, rev: tccgacttcatatttccacaa; Lgals1 fwd: ctctcgggtggagtcttctg, rev: 
ggtttgagattcaggttgctg; $T g f b 1$ fwd: tggagcaacatgtggaact, rev: cagcagccggttaccaag; Vegfa fwd: aaaaacgaaagcgcaagaaa, rev: tttctccgctctgaacaagg.

\section{Induction of Delayed Type Hypersensitivity (DTH) response}

Ovalbumin (1 mg/mL in PBS, Sigma-Aldrich) was emulsified at a $1: 1$ ratio in complete Freund's adjuvant (Sigma-Aldrich). Male C57BL/6 mice (6- to 8-weeks-old) were immunized by subcutan injection of $100 \mu \mathrm{g}$ ovalbumin/animal. Subcutan injection of PBS with complete Freund's adjuvant served as a control. Cells $\left(10^{6} \mathrm{MSCs} / \mathrm{animal}\right)$ or PBS were injected intraperitoneally in $200 \mu \mathrm{L}$ volume. After 4 days, DTH was initiated by challenging with $250 \mu \mathrm{g}$ heat-aggregated ovalbumin in $12.5 \mu \mathrm{L}$ PBS or PBS alone injected into the right or left hind footpad, respectively. After $48 \mathrm{~h}$, ovalbumin-induced footpad thickness was measured using a caliper and calculated as follows: $\left(\mathrm{T}_{48}\right.$ hours $-\mathrm{U}_{48}$ hours $)-\left(\mathrm{T}_{0}\right.$ hours $-\mathrm{U}_{0}$ hours $)$, where $\mathrm{T}$ and $\mathrm{U}$ are thickness of ovalbumin treated and ovalbumin untreated footpads, respectively. All animal studies were approved by the Animal Care and Use Committee of the National Medical Center (Budapest, Hungary) in accordance with the national and international law and regulations of animal experiments.

\section{Statistical analysis}

Statistical analysis was performed using one-way analysis of variance test (ANOVA) in GraphPad Prism Version 6.03 (GraphPad Software). When significant $(\mathrm{p}<0.05)$ by ANOVA, pairwise comparisons of experimental groups were carried out using Fisher's least significant difference (LSD) method as a post hoc test. For statistical analysis of qPCR data non-parametric
Formatted: Font: (Default) Times New Roman, $12 \mathrm{pt}$

Formatted: Font: (Default) Times New Roman, 12 pt

Formatted: Font: (Default) Times New Roman, 12 pt

Formatted: Font: (Default) Times New Roman, $12 \mathrm{pt}$

Formatted: Font: (Default) Times New Roman, $12 \mathrm{pt}$ 


\section{Results \\ Characterization of monoclonal MSC cell lines}

Each clone expressed uniformly Sca-1, CD29, CD44, CD106 and CD119 (Fig. 1) at similar degree and none of the clones expressed lineage specific markers CD11b and CD45 (Fig. 1).

In vitro osteoblast differentiation was assayed with Alisarin Red S staining showing that MSC2, MSC4 and MSC5 exhibited strong, MSC3 and MSC6 weak in vitro osteoblast differentiation

(Fig. 2A). During adipocyte differentiation, all MSC clones accumulated comparable amount of neutral lipids into intracellular lipid droplets (Fig. 2B, C), indicating that these cells had similar adipogenic differentiation potential.

\section{In vitro pro-angiogenic activity of MSC clones}

We have previously reported that MSCs and $\mathrm{H} 5 \mathrm{~V}$ endothelial cells spontaneously arranged into vessel-like structures within 3 days of co-culture [19]. Moreover, deficiency in galectin-1, a pro-angiogenic lectin in MSCs resulted in reduced formation of pre-vascular structures [19]. To determine whether individual MSC clones supported similarly or differently the shaping of these structures, in vitro pro-angiogenic assays were performed with the monoclonal MSC cultures. While neither MSC clones nor H5V endothelial cells formed prevascular structures alone, co-culturing any of the clones with $\mathrm{H} 5 \mathrm{~V}$ resulted in arrangement into pre-vascular structures (Fig. 3A) in similar extent (Fig. 3B). 


\section{MSC clones vary in in vitro immunosuppressive activity}

Immunomodulatory properties of MSC clones were assessed in vitro by analyzing their effect on Con A-activated T-cell proliferation. Proliferation of T-cells was robustfully diminished in the presence of MSC2, MSC4 and MSC5 while poorly inhibited by MSC3 and MSC6 (Fig. 4A, B). Differences were significant and the order of their inhibitory capacity was as follows: MSC2 $\geq$ MSC5 $>$ MSC4 $>$ MSC3 $>>$ MSC6 (Fig. 4B).

Our aim was to determine whether variability between the clones regarding their inhibitory activity was reflected in the expression levels of immunomodulatory factors. Therefore, the expression levels of mRNAs encoding NOS2, PTGS2 responsible for the production of antiinflammatory mediators, NO and PGE2, respectively and IDO1 creating a tryptophan deprived environment were analyzed. Relative Nos 2 mRNA level well coincided with anti-proliferative function of the clones as it was expressed at higher levels in MSC2, MSC5 (significant) and MSC4 (not significant) than in MSC3 and was undetectable in MSC6 (Fig. 5A). Expression of Ptgs2 did not show any remarkable difference between the clones (Fig. 5B). The two enzymes, NOS2 and PTGS2 seemed to be important in the inhibitory function of the most immunosuppressive clone MSC2. The inhibition of T-cell proliferation by MSC2 was blocked entirely with L-NMMA and partially with indomethacin, inhibitors of NOS2 and PTGS2, respectively (Fig. 6, Unstimulated MSC). In contrast, the presence of these inhibitors did not affect the activity of the least immunosuppressive clone MSC6 (Fig. 6, Unstimulated MSC). 
Expression of other immunomodulatory factors such as $T g f b 1$ (Supplementary Fig. S2) and Lgals1 (Fig. 3C) were similar and Idol mRNA expression couldn't be detected in any of the clones (Supplementary Fig. S3A).

To model the in vivo inflammatory environment in which MSCs act as anti-inflammatory cells, the monoclonal cell lines were pre-treated with Th1 type cytokines, IFN- $\gamma$ and TNF- $\alpha$ and the effect of the licenced MSC on T-cell proliferation was analyzed. Licensing by proinflammatory cytokines, MSC3 and MSC6 clones, which exerted poor inhibitory activity, blocked the T-cell proliferation at similar extent to the clones with strong inhibition. In contrast, licensing was not or barely able to further enhance immunosuppressive activity of MSC2, MSC4 and MSC5 (Fig. 4C). Expression of Nos2 gene largely increased in all clones to an equal level upon IFN- $\gamma$ and TNF- $\alpha$ treatment. Nevertheless, the degree of elevation was the most remarkable in clones with poor inhibitory activity (Fig. 5A). On the other hand, Ptgs2 expression was also upregulated in all clones, although much less than that of Nos2 gene (Fig. 5B). Furthermore, unstimulated MSC clones didn't express Ido1, unless they were pre-activated with IFN- $\gamma$ and TNF- $\alpha$. Pro-inflammatory cytokine treatment triggered Idol mRNA expression as well (Supplementary Fig. S3A).

To determine the potential role of anti-inflammatory mediators in the inhibition of T-cell proliferation under inflammatory conditions, anti-proliferative activities of the clones were blocked with inhibitors. Immunosuppressive activity of licenced MSC2 and MSC6 were assayed in the presence of L-NMMA and confirmed the crucial role of NO. On the other hand, the presence of indomethacin slightly affected MSC6 but not MSC2 activity (Fig. 6, MSC pre-treated with IFN- $\gamma+\mathrm{TNF}-\alpha$ ) suggesting a less pronounced function of PGE2. In addition, neither MSC2 nor MSC6 activities were influenced by IDO1 inhibitor 1-MT, independently from IFN- $\gamma$ and 


\section{Discussion}

It has been proposed that the heterogeneity of MSCs may be partially responsible for the divergent outcomes of MSC-based clinical trials [11]. Several studies reported that various MSC clones differed in differentiation potential into mesenchymal lineages [10]. Other functional properties, such as pro-angiogenic effect has not yet been extensively investigated at clonal level. In addition, the data regarding heterogeneity in immunosuppressive properties of MSC population is insufficient and meets discrepancy. While Xu et al. argued that single cell-derived MSC populations possessed uniform immunomodulating capacities [14] others demonstrated large differences in immunosuppression at clonal level $[15,16]$.

In the present study, clonal diversity of murine bone marrow MSCs was examined with a special focus on the in vitro and in vivo immunosuppression. Moreover, in vitro osteoblast and adipocyte 
differentiation and pro-angiogenic effect of the MSC clones were also compared as a part of the characterization of the clones.

In according to previous results regarding variable osteogenic differentiation of single cellderived human or murine MSCs [15,23-25] we found that the clones exhibited different osteoblast potential in vitro. On the other hand, the analyzed clones similarly differentiated toward adipocytes. It has recently been described that MSCs produce wide array of factors influencing endothelial cell growth and angiogenesis [26] and thereby inducing capillary-like structure formation in vitro [27,28]. We previously demonstrated that MSCs spontaneously formed interconnected pre-vascular structures on a galectin-1 dependent fashion when cocultured with $\mathrm{H} 5 \mathrm{~V}$ endothelial cells [19]. However, only one paper analyzed angiogenic activity of MSCs at clonal level [29]. Burns et al. reported that two telomerase-immortalized human MSC (hMSC-TERT20) clones distinctly formed cord-like structures due to their different extracellular matrix protein production and the key role of galectin-1 had been proven in in vitro and in vivo angiogenesis in serum-deprived condition in spite of equivalent expression of two major proangiogenic factors (VEGFA, ANGPT1) [29]. We analyzed the in vitro pro-angiogenic activity of MSC2-6 clones in a pre-vascular structure assay in which MSCs were co-cultured with H5V cells. The clones expressed comparable level of pro-angiogenic factors, including Vegfa, Angpt1 and Lgalsland accordingly, formed similar pre-vascular structures. The controversy between our and Burns's results may derive from the different experimental conditions, mainly that human MSCs were genetically modified and cultured under serum depriving condition.

The major aspect of this work has been the comparison of the immunomodulatory activity of MSCs at clonal level. The isolated MSC clones differently influenced the proliferation of Con A-activated T-cells ranging from $30 \%$ to $70 \%$ of inhibition. In this term, MSC2, MSC4 and 
MSC5 strongly inhibited T-cell proliferation while inhibitory activities of MSC3 and MSC6 were significantly weaker. Our results were in accordance with those published by others $[15,16]$ reporting difference between the immunosuppressive activities of single cell-derived MSC clones. The diversity in the inhibition of T-cell proliferation could be explained by the different expression of immunomodulatory gene Nos2, responsible for the generation of a crucial mediator, NO. Elevated level of Nos2 expression was found in naïve MSC2, MSC4 and MSC5, the clones representing high inhibitory activity. Whereas it was expressed at a lower level or was undetectable in MSC3 and MSC6, respectively, the clones slightly inhibiting T-cell proliferation. The central role of NO in inhibition of T-cell proliferation was also confirmed using NOS2 inhibitor, L-NMMA which blocked the inhibitory effect of the most immunosuppressive clone, MSC2. These results were in good agreement with previous experimental data $[15,16,30]$. Expression of Ptgs 2 playing role in PGE2 synthesis showed no significant difference among the clones. Studies examining the function of PGE2 in immunosuppression by murine MSCs produced controversial data namely PGE2 had either important [31] minor [30] or no role [1416]. Yet, the importance of PGE2 was unambiguously shown here by using an inhibitor of PTGS2, indomethacin. Interestingly, blocking NOS2 resulted in full inhibition of T-cell antiproliferative effect of MSC2, the most immunosuppressive clone while indomethacin only incompletely reversed T-cell growth. Our recent result [32] might serve an explanation for this phenomenon; PGE2 secretion by MSC seems to be promoted by a NO-dependent signaling pathway, since L-NMMA inhibits not only NO production but also partially diminishes PGE2 secretion, resulting in complete recovery of T-cell proliferation.

Recently, a growing body of data supports the idea that the biological functions of MSCs are strongly influenced by the surrounding microenvironment, especially the inflamed milieu. 
Activation, termed as licensing [33] is triggered by pro-inflammatory cytokines released from immune cells at the site of inflammation [15,34], albeit the polarization toward anti-inflammatory phenotype may depend on the concentration and duration of the stimulating agent or the type of the factor itself [33]. The site of inflammation abounds in pro-inflammatory mediators, including IFN- $\gamma$ and TNF- $\alpha$ [35]. For priming of MSC's immunosuppressive function, the combination of IFN- $\gamma$ and TNF- $\alpha$ or IL- $1 \alpha / \beta$ was recommended [15]. The production of numerous cytokines and chemokines involved in MSCs' T-cell inhibitory machinery in mouse or in human (IL-6, IL-8, IL-10, HGF, PD-L1, PGE2, NO and IDO1) are induced by priming MSCs with IFN- $\gamma$ and TNF- $\alpha$ $[15,31,36,37]$. In the present study, the combination of IFN- $\gamma$ and TNF- $\alpha$ was applied for the priming of MSC inhibitory activity to model an inflammatory milieu. The pre-treatment of MSC clones with IFN- $\gamma$ and TNF- $\alpha$ equated the inhibition of T-cell proliferation hence clones, MSC3 and MSC6, inhibiting poorly the T-cell proliferation, acquired similarly strong inhibitory activities to those of MSC2, MSC4 and MSC5. This result indicated that stimulation of MSC clones with IFN- $\gamma$ and TNF- $\alpha$ enhanced the immunosuppressive effect of otherwise nonfunctional single cell-derived MSC cultures. Indeed, licensing MSC clones resulted in a remarkable upregulation of Nos 2 and Ido1 and various moderate increase of Ptgs 2 gene expression in every MSC clone. Examining the role of inflammatory cytokines we found that the NOS2 expression was essential since its inhibitor L-NMMA reversed T-cell proliferation in licensed MSC2 and MSC6 clones. Inhibition of PGE2 synthase reversed only partially the suppression by MSC6 but did not affect that by MSC2. These results might allow the conclusion that MSC population has an intrinsic heterogeneity regarding the mediators of the immunosuppressive function, such as PTGS2. 
Induction of Ido1 mRNA expression under inflammatory conditions was the most striking since naïve clones did not express the gene at all whereas remarkable increase occurred upon IFN- $\gamma$ and TNF- $\alpha$ treatment. In spite of the high gene expression of Idol, IDO1 inhibitor, 1-MT did not affect activities of licensed MSC clones. Although IDO1 is an important factor in human MSC [38], its function in mouse MSCs is inconsistent. Even though Ido1 mRNA expression is inducible with pro-inflammatory cytokines, the IDO1 protein expression is undetectable in mouse MSC [39]. One possible explanation was served by Hucke et al. showing that an accelerated proteosomal degradation of IDO protein occurred upon NO production [40]. Accordingly, chemical inhibition of IDO1 in mouse MSCs did not affect MSC function on T-cell proliferation. $[15,30,38]$.

Experimental animal models clearly revealed that MSCs could be effective cell-based therapies in immunological pathologies $[17,18,41-43]$. Whether in vivo immunoregulatory property of MSCs was reflected at clonal level the effects of the most and least immunosuppressive clones, MSC2 and MSC6, respectively, were examined in ovalbumininduced delayed-type hypersensitivity (DTH) model. The in vitro results were validated in vivo, since MSC2 diminished whereas MSC6 did not affect DTH response when naïve MSC clones were applied. In contrast, pre-treatment of MSC6 with licensing cytokines IFN- $\gamma$ and TNF- $\alpha$ prior to intraperitoneal injection resulted in similar blocking effect of MSC6 to that of MSC2 indicating the increasing immunosuppressive function of an otherwise poorly acting clone. Our results were supported by the data obtained in GVHD model since pre-activation of MSCs resulted in more effective prevention of the disease [17].

Taken together, our experiments clearly show that murine MSC population possesses intrinsic heterogeneity regarding the immunosuppressive function of single cell-derived MSC 
clones. Variations between the clones can be at least partly, explained by the different expression of immunoregulatory factors. In this sense, NO is the key mediator while PGE2 is involved and IDO1 has no role in the suppressive activity of MSC clones. An important novel message of this work is that variability in the immune function of the different MSC clones can be abolished by licensing the cells by inflammatory cytokines prior to application for immunological assays or therapy of immune disorders. 


\section{References}

1. da Silva Meirelles L, PC Chagastelles and NB Nardi. (2006). Mesenchymal stem cells reside in virtually all post-natal organs and tissues. J Cell Sci 119:2204-2213.

2. Dominici M, K Le Blanc, I Mueller, I Slaper-Cortenbach, F Marini, D Krause, R Deans, A Keating, D Prockop and E Horwitz. (2006). Minimal criteria for defining multipotent mesenchymal stromal cells. The International Society for Cellular Therapy position statement. Cytotherapy 8:315-317.

3. Strioga M, S Viswanathan, A Darinskas, O Slaby and J Michalek. (2012). Same or not the same? Comparison of adipose tissue-derived versus bone marrow-derived mesenchymal stem and stromal cells. Stem Cells Dev 21:2724-2752.

4. Lalu MM, L McIntyre, C Pugliese, D Fergusson, BW Winston, JC Marshall, J Granton, DJ Stewart and G Canadian Critical Care Trials. (2012). Safety of Cell Therapy with Mesenchymal Stromal Cells (SafeCell): A Systematic Review and Meta-Analysis of Clinical Trials. PLoS ONE 7:e47559.

5. Murphy MB, K Moncivais and AI Caplan. (2013). Mesenchymal stem cells: environmentally responsive therapeutics for regenerative medicine. Exp Mol Med 45:e54.

6. Kurtzberg J, S Prockop, P Teira, H Bittencourt, V Lewis, KW Chan, B Horn, L Yu, JA Talano, E Nemecek, CR Mills and S Chaudhury. (2014). Allogeneic human mesenchymal stem cell therapy (remestemcel-L, Prochymal) as a rescue agent for severe refractory acute graft-versus-host disease in pediatric patients. Biol Blood Marrow Transplant 20:229-235. 
7. Karantalis V, DL DiFede, G Gerstenblith, S Pham, J Symes, JP Zambrano, J Fishman, P Pattany, I McNiece, J Conte, S Schulman, K Wu, A Shah, E Breton, J Davis-Sproul, R Schwarz, G Feigenbaum, M Mushtaq, VY Suncion, AC Lardo, I Borrello, A Mendizabal, TZ Karas, J Byrnes, M Lowery, AW Heldman and JM Hare. (2014). Autologous mesenchymal stem cells produce concordant improvements in regional function, tissue perfusion, and fibrotic burden when administered to patients undergoing coronary artery bypass grafting: The Prospective Randomized Study of Mesenchymal Stem Cell Therapy in Patients Undergoing Cardiac Surgery (PROMETHEUS) trial. Circ Res 114:1302-1310.

8. Lee JW, SH Lee, YJ Youn, MS Ahn, JY Kim, BS Yoo, J Yoon, W Kwon, IS Hong, K Lee, J Kwan, KS Park, D Choi, YS Jang and MK Hong. (2014). A randomized, openlabel, multicenter trial for the safety and efficacy of adult mesenchymal stem cells after acute myocardial infarction. J Korean Med Sci 29:23-31.

9. Bronckaers A, P Hilkens, W Martens, P Gervois, J Ratajczak, T Struys and I Lambrichts. (2014). Mesenchymal stem/stromal cells as a pharmacological and therapeutic approach to accelerate angiogenesis. Pharmacol Ther 143:181-196.

10. Pevsner-Fischer M, S Levin and D Zipori. (2011). The origins of mesenchymal stromal cell heterogeneity. Stem Cell Rev 7:560-568.

11. Phinney DG. (2012). Functional heterogeneity of mesenchymal stem cells: implications for cell therapy. J Cell Biochem 113:2806-2812.

12. Delorme B, J Ringe, C Pontikoglou, J Gaillard, A Langonne, L Sensebe, D Noel, C Jorgensen, T Haupl and P Charbord. (2009). Specific lineage-priming of bone marrow mesenchymal stem cells provides the molecular framework for their plasticity. Stem Cells 27:1142-1151. 
13. Friedenstein AJ, RK Chailakhyan and UV Gerasimov. (1987). Bone marrow osteogenic stem cells: in vitro cultivation and transplantation in diffusion chambers. Cell Tissue Kinet 20:263-272.

14. $\mathrm{Xu}$ G, L Zhang, $\mathrm{G}$ Ren, $\mathrm{Z}$ Yuan, $\mathrm{Y}$ Zhang, RC Zhao and $\mathrm{Y}$ Shi. (2007). Immunosuppressive properties of cloned bone marrow mesenchymal stem cells. Cell Res $17: 240-248$

15. Ren G, L Zhang, X Zhao, G Xu, Y Zhang, AI Roberts, RC Zhao and Y Shi. (2008). Mesenchymal stem cell-mediated immunosuppression occurs via concerted action of chemokines and nitric oxide. Cell Stem Cell 2:141-150.

16. Lei J, D Hui, W Huang, Y Liao, L Yang, L Liu, Q Zhang, G Qi, W Song, Y Zhang, AP Xiang and Q Zhou. (2013). Heterogeneity of the biological properties and gene expression profiles of murine bone marrow stromal cells. Int J Biochem Cell Biol 45:2431-2443.

17. Polchert D, J Sobinsky, GW Douglas, M Kidd, A Moadsiri, E Reina, K Genrich, S Mehrotra, S Setty, B Smith and A Bartholomew. (2008). IFN- $\gamma$ activation of mesenchymal stem cells for treatment and prevention of graft versus host disease. European journal of immunology 38:1745-1755.

18. Urban VS, J Kiss, J Kovacs, E Gocza, V Vas, E Monostori and F Uher. (2008). Mesenchymal stem cells cooperate with bone marrow cells in therapy of diabetes. Stem Cells 26:244-253.

19. Szebeni GJ, É Kriston-Pál, P Blazsó, RL Katona, J Novák, E Szabó, Á Czibula, R FajkaBoja, B Hegyi, F Uher, L Krenács, G Joó and É Monostori. (2012). Identification of 
Galectin-1 as a Critical Factor in Function of Mouse Mesenchymal Stromal CellMediated Tumor Promotion. PLoS ONE 7:e41372.

20. Pittenger MF, AM Mackay, SC Beck, RK Jaiswal, R Douglas, JD Mosca, MA Moorman, DW Simonetti, S Craig and DR Marshak. (1999). Multilineage potential of adult human mesenchymal stem cells. Science 284:143-147.

21. Garlanda C, C Parravicini, M Sironi, M De Rossi, R Wainstok de Calmanovici, F Carozzi, F Bussolino, F Colotta, A Mantovani and A Vecchi. (1994). Progressive growth in immunodeficient mice and host cell recruitment by mouse endothelial cells transformed by polyoma middle-sized $\mathrm{T}$ antigen: implications for the pathogenesis of opportunistic vascular tumors. Proc Natl Acad Sci U S A 91:7291-7295.

22. Gyorfy Z, S Benko, E Kusz, B Maresca, L Vigh and E Duda. (1997). Highly Increased TNF Sensitivity of Tumor Cells Expressing the Yeast $\Delta 9$-Desaturase Gene. Biochemical and Biophysical Research Communications 241:465-470.

23. Muraglia A, R Cancedda and R Quarto. (2000). Clonal mesenchymal progenitors from human bone marrow differentiate in vitro according to a hierarchical model. J Cell Sci 113 ( Pt 7):1161-1166.

24. Russell KC, MR Lacey, JK Gilliam, HA Tucker, DG Phinney and KC O'Connor. (2011). Clonal analysis of the proliferation potential of human bone marrow mesenchymal stem cells as a function of potency. Biotechnol Bioeng 108:2716-2726.

25. Levin S, M Pevsner-Fischer, S Kagan, H Lifshitz, A Weinstock, D Gataulin, G Friedlander and D Zipori. (2014). Divergent levels of LBP and TGFbeta1 in murine MSCs lead to heterogenic response to TLR and proinflammatory cytokine activation. Stem Cell Rev 10:376-388. 
26. Chen L, EE Tredget, PYG Wu and Y Wu. (2008). Paracrine Factors of Mesenchymal Stem Cells Recruit Macrophages and Endothelial Lineage Cells and Enhance Wound Healing. PLoS ONE 3:e1886.

27. Wu Y, L Chen, PG Scott and EE Tredget. (2007). Mesenchymal stem cells enhance wound healing through differentiation and angiogenesis. Stem Cells 25:2648-2659.

28. Sorrell JM, MA Baber and AI Caplan. (2009). Influence of adult mesenchymal stem cells on in vitro vascular formation. Tissue Eng Part A 15:1751-1761.

29. Burns JS, M Kristiansen, LP Kristensen, KH Larsen, MO Nielsen, H Christiansen, J Nehlin, JS Andersen and M Kassem. (2011). Decellularized matrix from tumorigenic human mesenchymal stem cells promotes neovascularization with galectin-1 dependent endothelial interaction. PLoS One 6:e21888.

30. Sato K, K Ozaki, I Oh, A Meguro, K Hatanaka, T Nagai, K Muroi and K Ozawa. (2007). Nitric oxide plays a critical role in suppression of T-cell proliferation by mesenchymal stem cells. Blood 109:228-234.

31. English K, FP Barry, CP Field-Corbett and BP Mahon. (2007). IFN-gamma and TNFalpha differentially regulate immunomodulation by murine mesenchymal stem cells. Immunol Lett 110:91-100.

32. Hegyi B, G Kudlik, E Monostori and F Uher. (2012). Activated T-cells and proinflammatory cytokines differentially regulate prostaglandin E2 secretion by mesenchymal stem cells. Biochem Biophys Res Commun 419:215-220.

33. Krampera M. (2011). Mesenchymal stromal cell 'licensing': a multistep process. Leukemia 25:1408-1414. 
34. Shi Y, G Hu, J Su, W Li, Q Chen, P Shou, C Xu, X Chen, Y Huang, Z Zhu, X Huang, X Han, N Xie and G Ren. (2010). Mesenchymal stem cells: a new strategy for immunosuppression and tissue repair. Cell Res 20:510-518.

35. O'Shea JJ, A Ma and P Lipsky. (2002). Cytokines and autoimmunity. Nat Rev Immunol 2:37-45.

36. Hemeda H, M Jakob, AK Ludwig, B Giebel, S Lang and S Brandau. (2010). Interferongamma and tumor necrosis factor-alpha differentially affect cytokine expression and migration properties of mesenchymal stem cells. Stem Cells Dev 19:693-706.

37. Ryan JM, F Barry, JM Murphy and BP Mahon. (2007). Interferon-gamma does not break, but promotes the immunosuppressive capacity of adult human mesenchymal stem cells. Clin Exp Immunol 149:353-363.

38. Ren G, J Su, L Zhang, X Zhao, W Ling, A L'Huillie, J Zhang, Y Lu, AI Roberts, W Ji, H Zhang, AB Rabson and Y Shi. (2009). Species variation in the mechanisms of mesenchymal stem cell-mediated immunosuppression. Stem Cells 27:1954-1962.

39. Meisel R, S Brockers, K Heseler, O Degistirici, H Bulle, C Woite, S Stuhlsatz, W Schwippert, M Jager, R Sorg, R Henschler, J Seissler, D Dilloo and W Daubener. (2011). Human but not murine multipotent mesenchymal stromal cells exhibit broad-spectrum antimicrobial effector function mediated by indoleamine 2,3-dioxygenase. Leukemia 25:648-654.

40. Hucke C, CR MacKenzie, KD Adjogble, O Takikawa and W Daubener. (2004). Nitric oxide-mediated regulation of gamma interferon-induced bacteriostasis: inhibition and degradation of human indoleamine 2,3-dioxygenase. Infect Immun 72:2723-2730. 
41. Zappia E, S Casazza, E Pedemonte, F Benvenuto, I Bonanni, E Gerdoni, D Giunti, A Ceravolo, F Cazzanti, F Frassoni, G Mancardi and A Uccelli. (2005). Mesenchymal stem cells ameliorate experimental autoimmune encephalomyelitis inducing T-cell anergy. Blood 106:1755-1761.

42. Bartholomew A, C Sturgeon, M Siatskas, K Ferrer, K McIntosh, S Patil, W Hardy, S Devine, D Ucker, R Deans, A Moseley and R Hoffman. (2002). Mesenchymal stem cells suppress lymphocyte proliferation in vitro and prolong skin graft survival in vivo. Exp Hematol 30:42-48.

43. Augello A, R Tasso, SM Negrini, R Cancedda and G Pennesi. (2007). Cell therapy using allogeneic bone marrow mesenchymal stem cells prevents tissue damage in collageninduced arthritis. Arthritis Rheum 56:1175-1186. 


\section{Author Disclosure Statement}

The authors declare no competing financial interests. 


\section{Figure legend}

FIG. 1. Expression of cell surface markers of monoclonal MSC lines. MSC clones 2-6 were labeled with antibodies to CD11b, CD45, Sca-1, CD29, CD44, CD106 or CD119 (black lines). The negative controls were isotype matching immunoglobulins (grey shadowed area). Samples were then analyzed with flow cytometry.

FIG. 2. In vitro adipogenic and osteogenic differentiation of MSC clones. Cells were induced to differentiate toward osteoblastic (A) and adipocytic (B) lineage. In osteogenic cultures calcium accumulations were stained with Alisarin Red S on the $14^{\text {th }}$ day (A). Adipogenic cultures were fixed and stained with AdipoRed ${ }^{\mathrm{TM}}$ on the $3^{\text {rd }}$ day (B) and lipid accumulation was quantified by flow cytometry (C). The pictures are representatives of 3 independent experiments. Scale bar $=50 \mu \mathrm{m}(\mathrm{A}$ and $\mathrm{B})$

FIG. 3. Monoclonal MSC lines exhibit similar pro-angiogenic activity. MSCs were co-cultured with or without $\mathrm{H} 5 \mathrm{~V}$ in $1: 1$ ratio for 3 days. Pre-vascular structures were visualized with Olympus Cell-R fluorescence microscope using UPlanSApo 4x/0.16 objective (representative images selected from three independent experiments) (A). Lengths of the structures were measured in 5 randomly selected non-overlapping areas of co-plated cells using CellR Imaging Software. Averages and deviations were calculated using data of three independent experiments (B). Expressions of proangiogenic factors, Angpt1, Vegfa and Lgals1, were determined from total mRNA extract prepared from MSC2-6 with qPCR. Gapdh expression served as internal control. Results of three independent experiments were used to draw the graphs (C). 
FIG. 4. MSC cell lines vary in immunosuppressive activity. Cytofluorimetric profiles of CFSE labeled T-cells under different conditions are presented (representative experiment) (A).Freshly isolated, CFSE-labeled lymph node cells were co-cultured with or without MSC clones at 40 to 1 ratio in the presence of Con A. The day before co-culture with T-cells MSC were plated without (B) or with $100 \mathrm{ng} / \mathrm{mL} \mathrm{IFN- \gamma}$ and $50 \mathrm{ng} / \mathrm{mL}$ TNF- $\alpha$ for 24 hours (C). T-cell proliferation was evaluated after 72 hours by flow cytometry and data were analyzed by ModFit $\mathrm{LT}^{\mathrm{TM}}$ software. The data shown on (B) and (C) are the means of 5 independent experiments. Each experiment was carried out in triplicates $(\mathrm{n}=15)$. n.s. $=$ not significant, $\mathrm{p}>0.05, * \mathrm{p}<0.05 ; * *$ $\mathrm{p}<0.01 ; * * * \mathrm{p}<0.001$

FIG. 5. Expression levels of genes affecting immunosuppressive function of MSCs. Total RNA was extracted from cells cultured for $24 \mathrm{~h}$ in the absence or presence of $100 \mathrm{ng} / \mathrm{mL}$ IFN- $\gamma$ and $50 \mathrm{ng} / \mathrm{mL}$ TNF- $\alpha$ and expression levels of Nos2 (A), Ptgs2 (B) were analyzed by qPCR. Gapdh served as a housekeeping gene. The results are the averages of 2 independent experiments + S.E.M.

FIG. 6. The role of NO and PGE2 in the inhibition of T-cell proliferation by MSC2 and MSC6. MSCs were plated on 96-well plates, left unstimulated or pre-activated with $100 \mathrm{ng} / \mathrm{mL}$ IFN- $\gamma$ and $50 \mathrm{ng} / \mathrm{mL}$ TNF- $\alpha$ for 24 hours. After 24 hours, MSCs were washed with DMEM, co-cultured with freshly isolated, CFSE-labeled lymph node cells in 1 to 40 ratio with or without $1 \mathrm{mM} \mathrm{L-NMMA}$ or $10 \mu \mathrm{M}$ indomethacin (Indo). Proliferation of T-cells was stimulated by Con A. After 72 hours of co-culture of MSCs and T-cells, proliferation of T-cells was assessed by cytofluorometry and data were analyzed by ModFit $\mathrm{LT}^{\mathrm{TM}}$ software. The figure shows the percent of 
proliferating T-cells.. Con A-activated T-cells cultured with or without L-NMMA or indomethacin in the absence of MSCs served as positive controls. The data are the representative of three independent experiments $+\mathrm{SD}$. The experiments were performed in triplicate. n.s. $=$ not significant $\mathrm{p}>0.05 ; * \mathrm{p}<0.05 ; * * \mathrm{p}<0.01$; $* * * p<0.001$.

FIG. 7. Effect of intraperitoneal injection of MSC2 and MSC6 in ovalbumin-induced delayed type hypersensitivity (DTH) model. Hypersensitivity was triggered in male C57BL/6 mice with subcutaneous administration of ovalbumin. At the same time, mice were injected intraperitoneally with $10^{6}$ MSC2 or $10^{6}$ MSC6 untreated or pretreated with IFN- $\gamma$ and TNF- $\alpha$ in PBS or with PBS alone. After 4 days, heat aggregated ovalbumin was injected into the right and PBS in the left hind footpad. After 48 hours, ovalbumin-induced footpad thickness increment was measured. RFI, relative footpad increment, was calculated as follows: $R F I=\left(\operatorname{treated}_{48 \mathrm{~h}}\right.$ untreated $\left._{48 \mathrm{~h}}\right)-\left(\right.$ treated $_{0 \mathrm{~h}}-$ untreated $\left._{0 \mathrm{~h}}\right)$. The data are the means of two independent experiments. One-way ANOVA, Fisher's LSD multiple comparison test was used for statistical analysis, n.s. $\mathrm{p}>0.05, * \mathrm{p}<0.05 ; * * \mathrm{p}<0.01$. Black lines mark the average footpad thickness increment in each experimental group. 


1
2
3
4
5
6
7
8
9
10
11
12
13
14
15
16
17
18
19
20
21
22
23
24
25
26
27
28
29
30
31
32
33
34
35
36
37
38
39
40
41
42
43
44
45
46
47
48
50
59
50
52
53
50

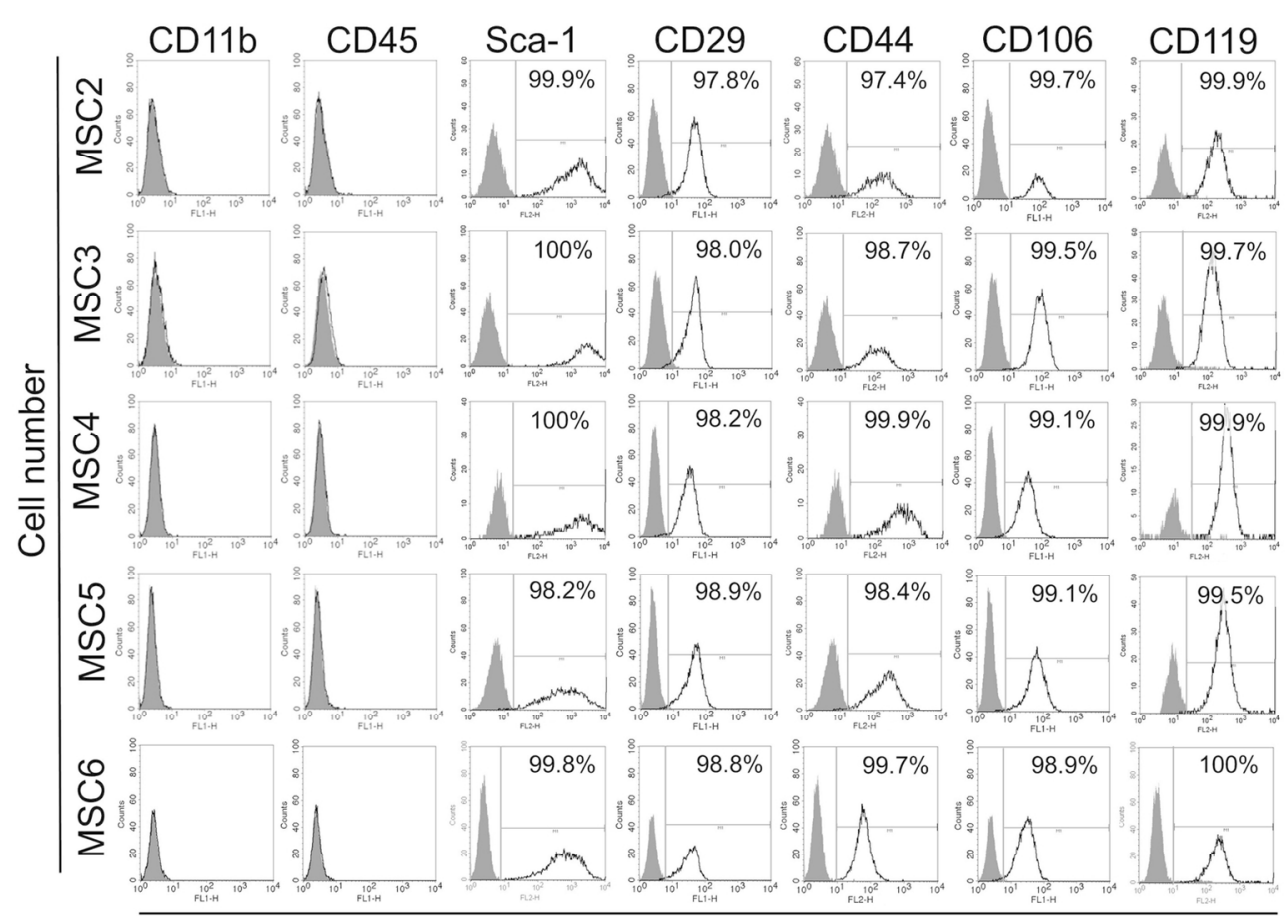

FIG. 1

Fluorescence intensity

$138 \times 103 \mathrm{~mm}(300 \times 300 \mathrm{DPI})$ 


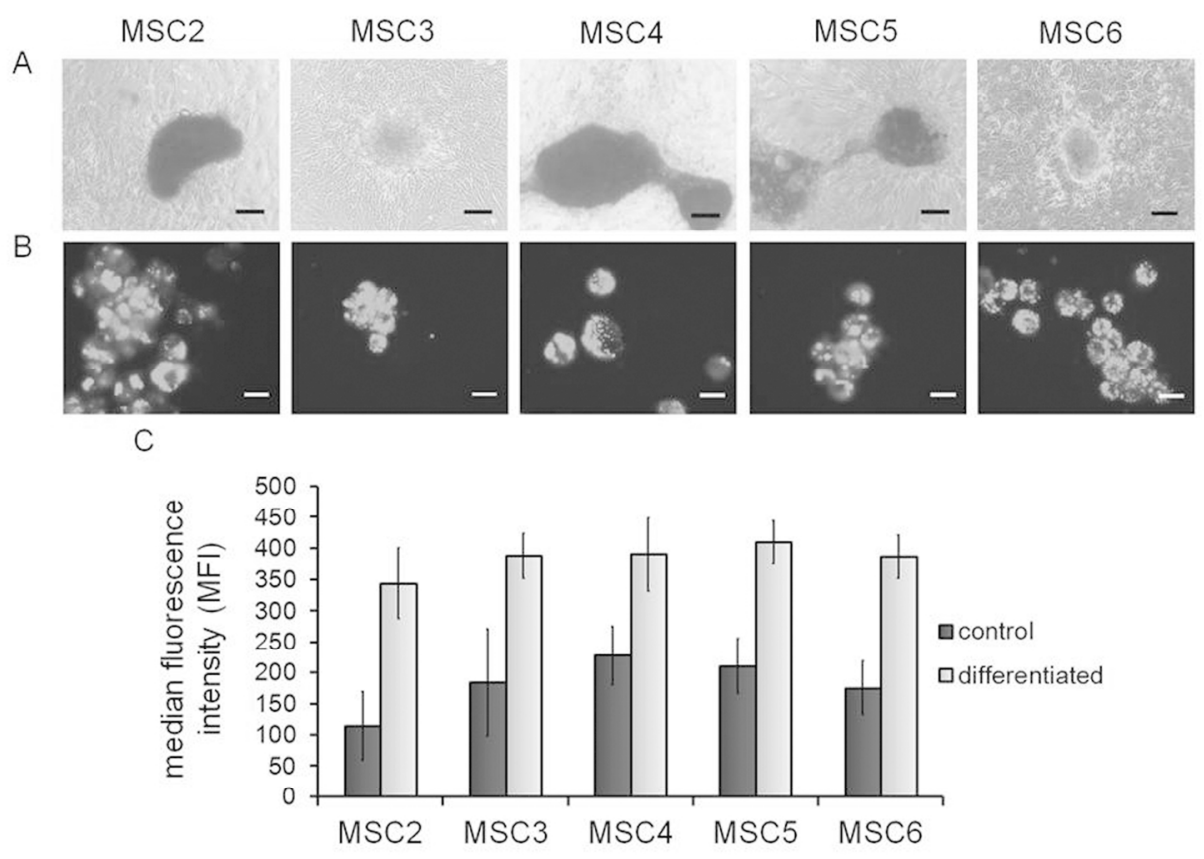

FIG. 2

$138 \times 103 \mathrm{~mm}(300 \times 300 \mathrm{DPI})$ 
A
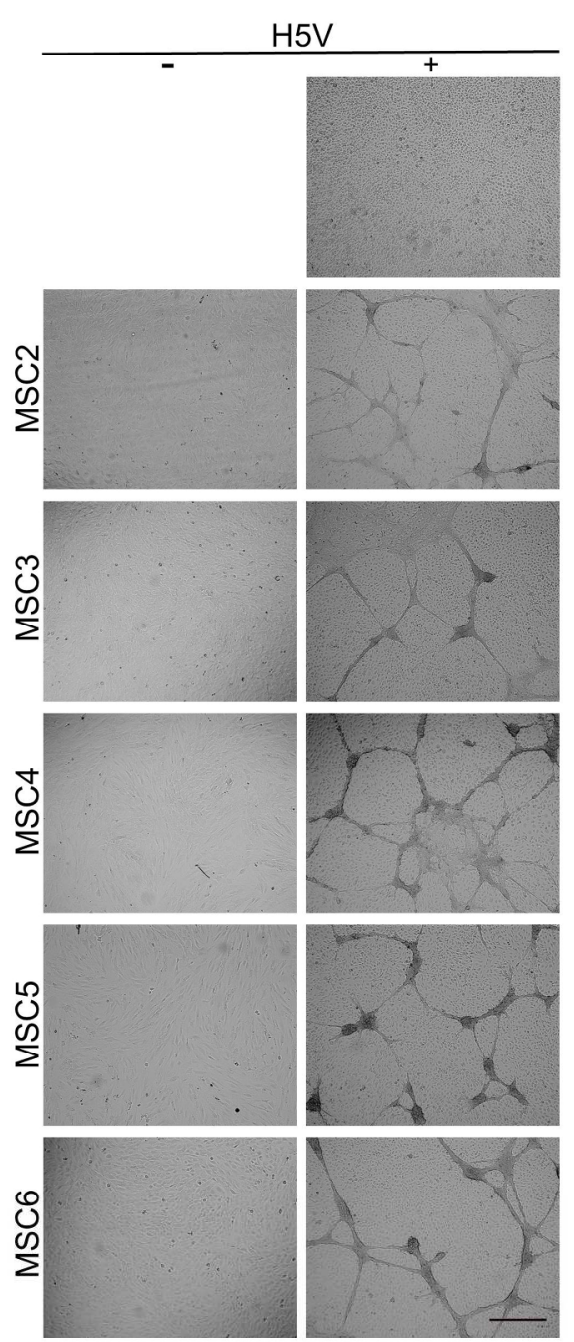

FIG. 3
B

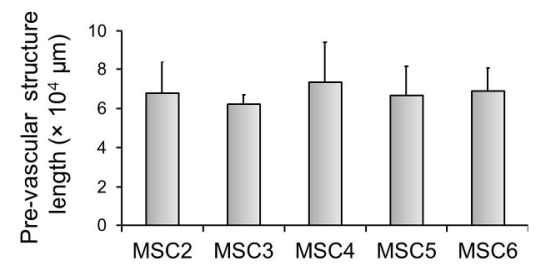

C

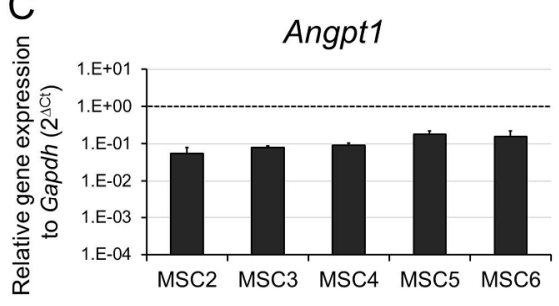

---- Gapdh mRNA expression

Vegfa

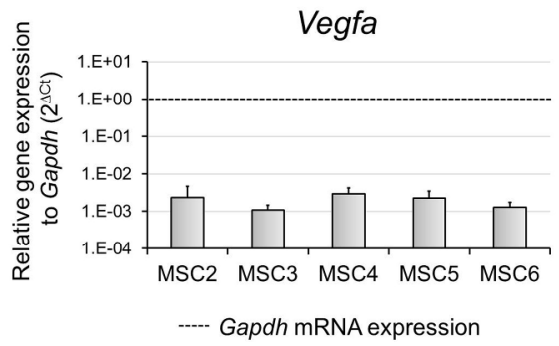

Lgals1

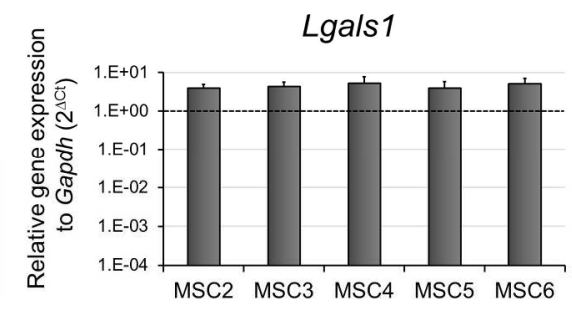

---- Gapdh mRNA expression

$246 \times 328 \mathrm{~mm}(300 \times 300 \mathrm{DPI})$ 
A

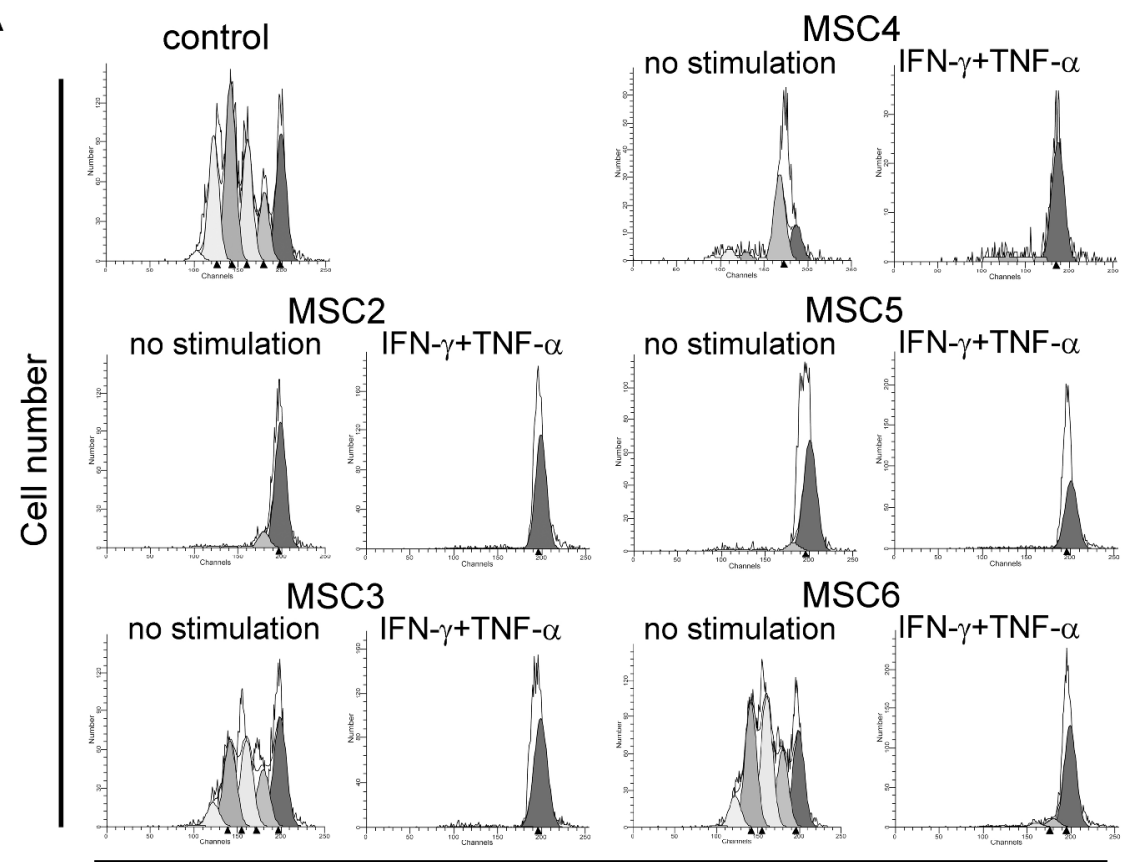

Fluorescence intensity

B

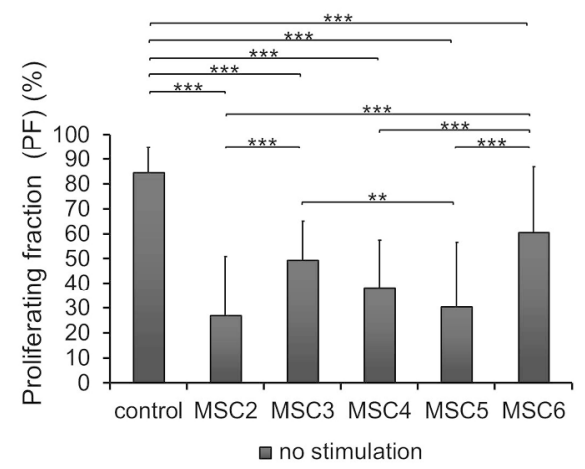

C

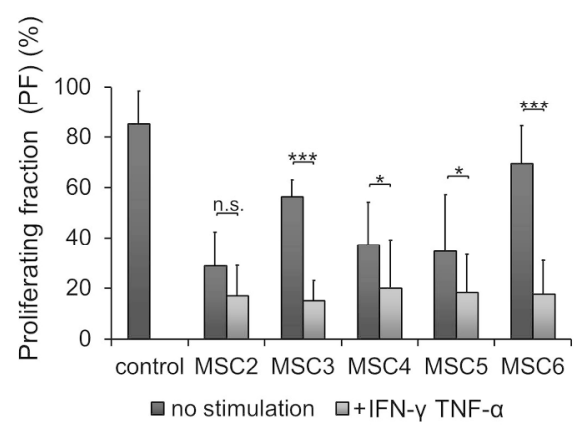

FIG. 4 


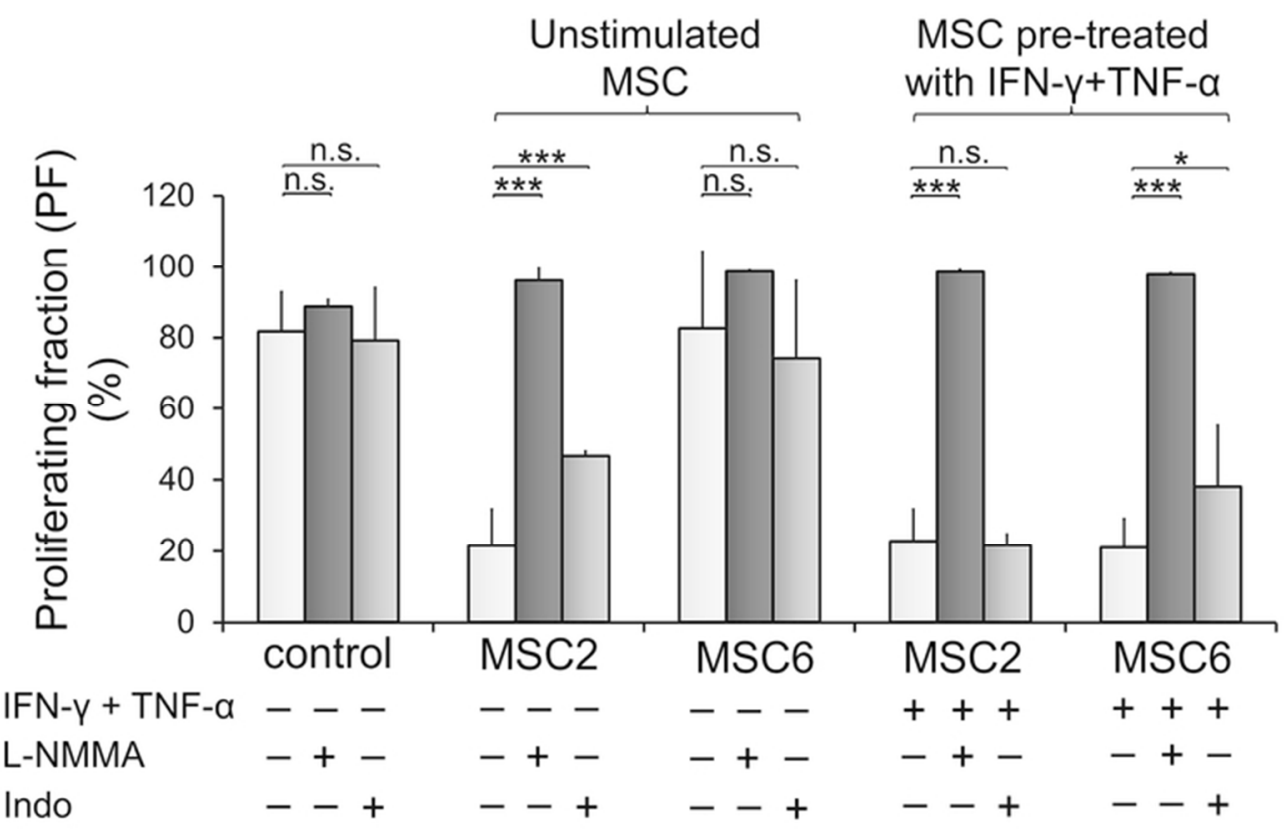

FIG. 6

$63 \times 47 \mathrm{~mm}(300 \times 300 \mathrm{DPI})$ 

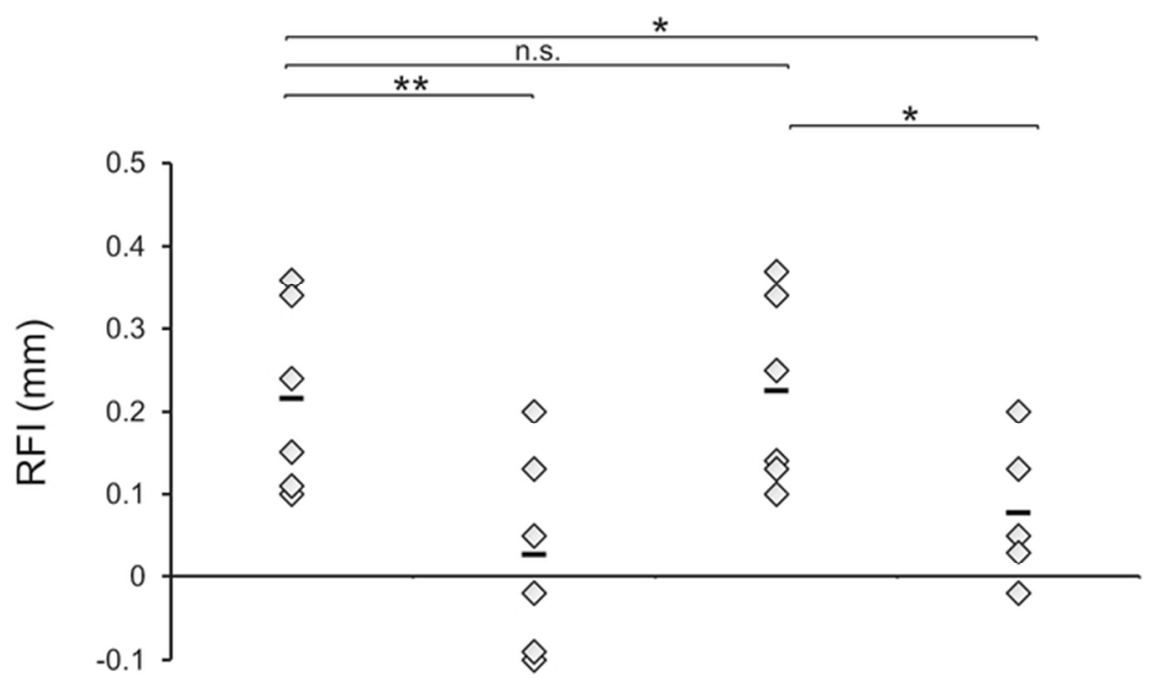 ovalbumin ovalbumin ovalbumin ovalbumin MS̊22
FIG. 7

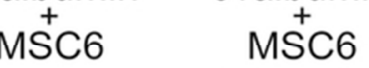
pre-treated with IFN- $y+$ TNF- $\alpha$

$63 \times 47 \mathrm{~mm}(300 \times 300 \mathrm{DPI})$ 


\section{Supplementary Data}

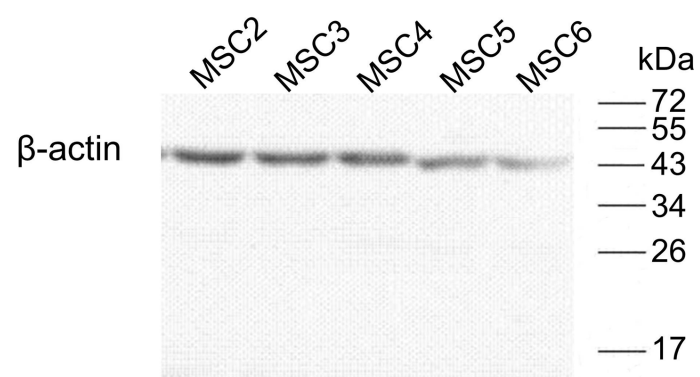

Gal-1

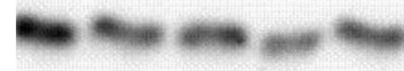

$-10$

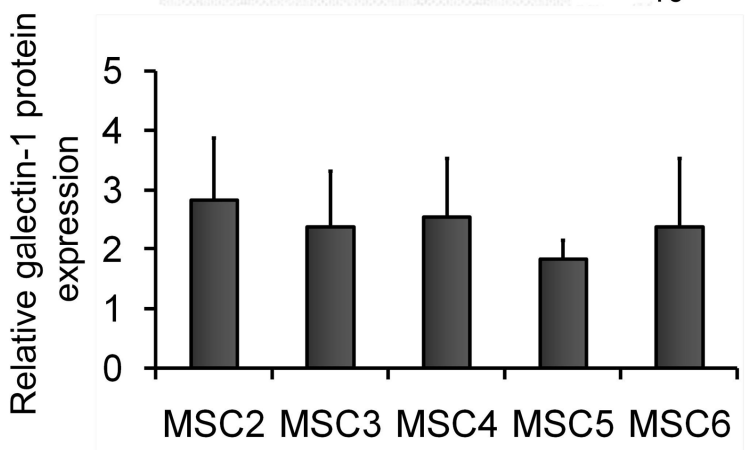

SUPPLEMENTARY FIG. S1. MSC clones express similar amount of galectin-1 (Gal1). MSCs were lysed in RIPA buffer, and $30 \mu \mathrm{g}$ protein of the lysates/sample were analyzed by Western blot after running the samples on a $10 \%$ SDS-polyacrylamide gel. Polyclonal rabbit anti-Gal-1 and HRP-conjugated anti-rabbit immunoglobulins were applied for Gal-1 detection. Rabbit anti- $\beta$-actin was used as loading control. Density of the bands was determined by VisionWorks ${ }^{\circledR}$ LS Image Acquisition and Analysis Software (Ultra-Violet Products). 
Tgfb1

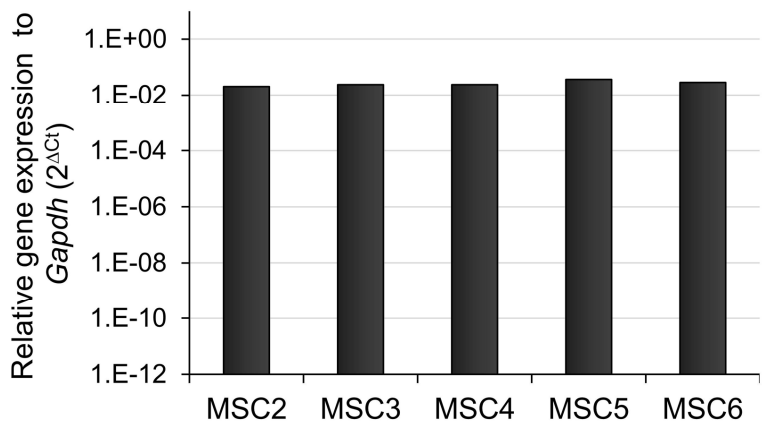

SUPPLEMENTARY FIG. S2. $T g f b 1$ mRNA expression levels of MSC clones under normal culture conditions. After 2 days of culture, total RNA was isolated from cells and analyzed by qPCR. Data were normalized to the expression level of housekeeping gene Gapdh.
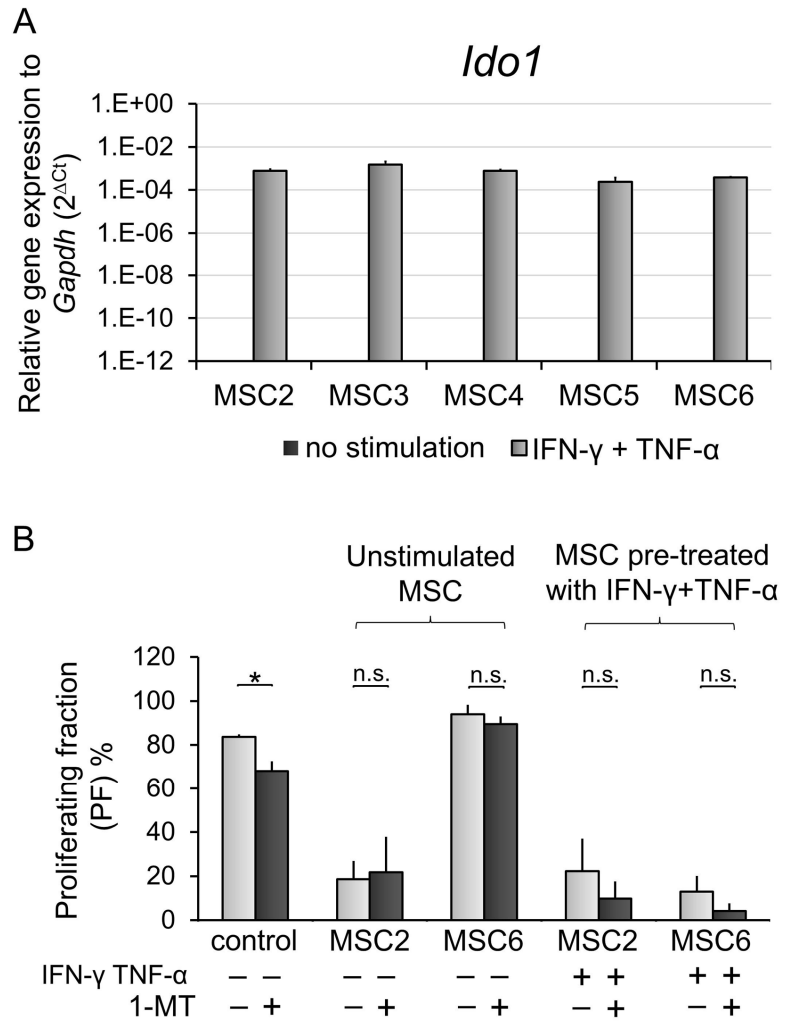

SUPPLEMENTARY FIG. S3. The expression and role of IDO1 in the inhibition of unstimulated and pre-activated MSC2 and MSC6. (A) MSCs were treated with 
$100 \mathrm{ng} / \mathrm{mL}$ IFN- $\gamma$ and $50 \mathrm{ng} / \mathrm{mL}$ TNF- $\alpha$ for 24 hours or left unstimulated. After 24 hours cytokine treatment total RNA was isolated and Idol gene expression analyzed by qPCR. Gapdh expression served as an internal control. (B) MSCs were plated on a 96-well culture plate, pre-treated with $100 \mathrm{ng} / \mathrm{mL}$ IFN- $\gamma$ plus $50 \mathrm{ng} / \mathrm{mL}$ TNF- $\alpha$ for 24 hours or left unstimulated. After 24 hours, MSCs were washed with medium, cocultured with freshly isolated, CFSE-labeled lymph node cells in 1 to 40 ratio with or without $1 \mathrm{mM}$ 1-MT. T-cells were activated with Con A. After 72 hours of co-culture, proliferation of T-cells was assessed by flow cytometry and data were analyzed by ModFit $\mathrm{LT}^{\mathrm{TM}}$ Version 2.0. software. The figure shows the percent of proliferating Tcells. Con A-activated T-cells alone with or without $1 \mathrm{mM}$ 1-MT served as positive controls. The data are the representative experiment $+\mathrm{SD}$, which was carried out in triplicate. n.s. $=$ not significant $\mathrm{p}>0.05$ 